\title{
The Performance Accountability of the Public Bureaucracy in Prevention of Corruption, Collusion and Nepotism Behavior
}

\author{
Bambang Martin Baru ${ }^{1}$ Sripeni Rusbiyanti ${ }^{1} \quad$ Heru Drajat Sulistyo $^{2}$ \\ 1.Faculty of Social and Political Sciences, Merdeka Madiun University, Indonesia \\ 2.Faculty of Law, Soeryo Ngawi University, Indonesia
}

\begin{abstract}
Corrupt behavior in the bureaucratic environment tends to increase, and is even carried out in various new modes. The government's efforts to prevent corruption have been carried out by establishing a KPK institution, and or through various regulations to minimize the occurrence of criminal acts of bureaucratic corruption. There are several factors that encourage corruption, namely internal factors that exist within the individual, and external factors that develop in their environment. Internal factors are closely related to personal qualities that are shown through moral characters such as integrity or honesty. Meanwhile, external factors are triggered due to pressure and encouragement from the environment that allows for deviant actions. One of the prevention strategies carried out in a bureaucratic environment is to increase the accountability of the performance of public institutions. Accountability is a form of accountability from the government apparatus for all its policies and actions to the public. By adhering to the principle of accountability, it will minimize the occurrence of irregularities in carrying out its duties and functions. For that, it is necessary to strengthen and develop a system of accountability that is precise and clear, so that governance can run properly and accountably.
\end{abstract}

Keywords: Accountability, public bureaucracy, corruption.

DOI: $10.7176 /$ DCS10-9-05

Publication date:September $30^{\text {th }} 2020$

\section{BACKGROUND}

The widespread practice of KKN (Corruption, Collusion, and Nepotism) in the bureaucratic environment creates public distrust of the performance of the public bureaucracy. The administration of public services which is known to be convoluted, takes a long time to complete, and even requires high costs has been prevalent in both the central bureaucracy and the regional bureaucracy. The practice of KKN which has been occurring so far has made the bureaucracy further away from society, the bureaucracy is less responsive and less sensitive to the interests of society. It is like $\mathrm{KKN}$ as a disease has undermined the body of the bureaucracy and has even spread to various joints of bureaucratic life.

Quantitatively, KKN is an action that is detrimental to society because KKN only benefits individuals and / or certain groups. The term KKN consists of three elements, namely corruption, collusion and nepotism. Corruption is an act of manipulation or embezzlement by government officials, and collusion is an action taken by government officials or political and private figures by working together to exploit public resources for personal and / or group interests. Meanwhile, nepotism is an act that is carried out deliberately by exploiting one's position for personal, family, and colleague interests in ways that violate ethics and legal norms. Corruption cases that occur in the bureaucratic environment are increasing and there are even no signs of reduced corruption practices. In ICW's presentation, there were 271 corruption cases handled in 2019 with a total of 580 suspects and total state losses reaching Rp. 8.04 trillion. The corruption cases recorded by ICW were cases investigated by the KPK, the Attorney General's Office, and the Police during January 1, 2019 until 31 December 2019. The KPK has handled 62 cases with 155 suspects, the Attorney General has handled 109 cases with 216 suspects, and the Police have handled 100 cases with 209 suspects. ICW data shows that bribery corruption cases are still dominant with a total of 51 cases and a total value of bribes reaching Rp. 169.5 billion and the value of money laundering reaching Rp. 46 billion (Ardito Ramadhan, 2020). Indeed, in the reality of life, there is no single social system that is free from the elements of $\mathrm{KKN}$, because there are individuals who prefer shortcuts in carrying out various affairs of their interest, even though it is realized that what is being done is very detrimental to the interests of the wider community. Entrepreneurs do not hesitate to pay bribes to government officials in order to get their business permits easier, and one day they will repeat themselves to bribes to these government officials. The proliferation of KKN practices will damage the government structure and hinder the process of public services. It should be remembered that to eradicate the disease of corruption in the public bureaucracy, it cannot be done by issuing several regulations that contain legal sanctions for $\mathrm{KKN}$ actors, but what is needed is the commitment of all bureaucratic officials to avoid irregularities that lead to criminal acts of corruption. According to Robert G. Vaughn (1980) in Dwiyanto, et.al (2006: 99), states that: "accountability mechanism act to ensure that agencies and agency leadership have a vested interest in maintaining a structure of incentives that benefit the public. The law alone cannot build such strctures; the law cannot fully protect the employee who exposes corruption or wrongdoing, and the law cannot make the day-to-day decitions of personnel and management officials that do so much to establish 
the atmosphere and character of the public service". This shows that efforts to eradicate corruption, collusion and nepotism will not be successful without being followed by a commitment from the government to create an accountable apparatus. However, it also needs to be realized that maintaining accountability and instilling a sense of responsibility is much more difficult than taking curative action, so that policy makers take more repressive actions to overcome the problem of corruption.

One of the factors of low accountability for bureaucratic performance is due to cultural factors that have been embedded since the Dutch colonial administration. Bureaucratic behavior shows more as an official than as a public servant who serves the interests of the people. The concept of "pangreh praja" is still embedded in bureaucratic thinking and behavior patterns. According to Dwiyanto, et.al (2006: 117), the influence of traditional values in the pangreh praja concept resulted in a strong patternalistic culture. The public bureaucracy is then arranged in a very strict hierarchical structure, so that the end of power lies not in the service users but with the top bureaucratic officials. Thus the public bureaucracy autonomously develops a cultural system of privileges to superiors excessively. In practice, such a tendency will result in unhealthy administrative mechanisms. The most obvious is the emergence of non-objective reports called ABS (As long as you are happy), the giving of tribute which sometimes leads to abuse of office, and so on. Low accountability is also due to gaps between policy formulation and implementation. Policy makers lack sensitivity to the realities of problems faced by society. They are so easy to generalize about problems based only on assessments that occur on the surface of social reality. In terms of what appears on the surface does not represent the real problems that occur in society. Not to mention that there is a gap in policy implementation between the expected goals and the reality, so that many people become the target of the policy untouched. This is because the policy implementers do not understand the vision, mission and policy objectives, and it is also supported by the development of a culture of behavior for officials who are kinship / kinship oriented. As a result, determining the target community is very much dependent on the implementing official.

In addition, the problem of low bureaucratic accountability in public services is also caused by the unclear between political power and administrative power. The overlap of political and administrative power makes services ineffective because administrative officials always consider the political dimension in public services, as a result, causing injustice in the eyes of the public in responding to public services in general. During the New Order government, the bureaucracy was far from dealing with political problems, so that the bureaucracy could work more efficiently because it did not have to consider its political aspects. However, in such a situation, it makes the bureaucracy less sensitive to the needs of the community, and at the same time develops a mono-loyalty system to repress the people's aspirations. For this reason, increasing the accountability of bureaucratic performance needs to be improved so that the bureaucracy has a culture to always be accountable for whatever is done. Besides taking firm action against the perpetrators who are proven to have committed violations, sanctions or laws must be enforced in order to provide a deterrent effect. According to Dwiyanto, et.al (2006: 123), a strategy to create an accountable government and a strategy to eradicate corruption, collusion and nepotism are basically two sides of a coin. The consistent attitude of the community is the most important asset to fight corruption. Every element of society and state administrators must always have great concern for the issues of corruption and take preventive measures whenever symptoms of corruption appear wherever they are. Allowing corruption to flourish means increasing the number of hidden crimes in society. When people are accustomed to corrupt behavior patterns, it will be increasingly difficult to find the strengths to combat corruption. Under these circumstances, the confidence of a group of honest people will slowly wear off, so that the courage to say that corruption is bad can be lost. People become compromising on various kinds of acts of fraud which are actually categorized as corruption. The emergence of phrases such as "honest corruption", "justified corruption", or "forced corruption" to mention several acts of corruption that exist around them, shows that there has been a shift in values that have resulted in the emergence of people's discriminatory attitudes towards the practice. corruption.

\section{LITERATURE REVIEW.}

The term corruption comes from the Latin "Coruption or Corruptus" which means rotten, damaged, destabilizes, or distorts. In the Indonesian dictionary, corruption is fraud or misuse of state finances (companies and so on) for personal or other people's interests. According to Sudomo in the BPKP (1999), there are three definitions of corruption, first controlling or obtaining money from the state illegally and used for one's own interests, second, abusing authority, abuse of power. This authority is misused to provide other facilities and benefits. The third is illegal fees. This extortion is an interaction between two people, usually officials with local residents, which means that the officials provide a facility and so on, and certain members of the community give reward for what the relevant officials do. Blak's Law Dictionary in the BPKP (1999), the view of the United States legal community on the notion of corruption according to the most popular legal dictionary in the United States: An act done with an intent to give some advantage inconsistent with official duty and the rights of others. The act of an official or fiduciary person who unlawfully and wrongfully uses his station or characterto procure some benefit for himself or for another person, contrary to duty and the rights of others. 
According to Muhammad Shoim (2009), corruption seen from the process of corruption can be divided into three forms: (1). Graft, namely internal corruption. This corruption occurs because they have positions and positions in the office. With their authority, subordinates cannot refuse requests from their superiors. (2). Bribery (bribery, bribery), namely acts of corruption that involve other people outside of themselves (their institution). This action is carried out with the intention of influencing objectivity in making decisions or making decisions that will benefit the giver, bribe or bribe. (3) Nepotism, which is an act of corruption in the form of a tendency to make decisions that are not based on objective, rational considerations, but are based on "nepotic" and "kinship" considerations. Meanwhile, when viewed from the nature of corruption, it can be divided into two, namely: (a). Individualist corruption, namely irregularities committed by one or several people in an organization and developing a mechanism to emerge, disappear and if caught by the perpetrator of corruption will be subject to punishment that can be cornered, shunned, criticized, and even ended his career fate. (b). Systemic corruption, namely corruption committed by most (mostly) people in an organization (involving many people) (eprints.walisongo.ac.id/3925/3/104211009_Bab2.pdf).

Corruption in the bureaucratic environment has a very detrimental impact on the interests of the state, nation and society, so corrupt behavior is considered a serious crime and the culprit (corruptor) must be punished as severely as possible. Corruption is also considered moral corruption, because it involves immoral behavior that deviates from the prevailing regulations. Moral corruption orientation is not intended to serve the interests of the people but for the personal interests / authorities. The constitution as a basis for carrying out its duties is no longer a priority but is used for personal gain. Based on Law Number. 31 of 1999 concerning the Eradication of Corruption Crimes states that corruption is an act of enriching oneself, abuse of power, giving and promising something to an official or judge, cheating, committing embezzlement, and receiving gifts related to responsibilities that are carried out. Corruption is clearly stated as an act of abuse of position or authority by a person for personal gain. Not much different from the opinion of Brooks (Klitgaard, 2001) the definition of corruption, namely: "Intentionally making mistakes or neglecting duties that are known to be an obligation or without the right to use power with the aim of obtaining more or less personal benefits" (Kompas.com). Corruption is an act that makes mistakes or negligence of its duties and functions that have the potential to benefit individuals. Error or negligence is an act, intentional or unintentional, which results in losses for the state.

The problem of corruption is not simple but very complex which involves various factors that cause corruption, according to Syed Hussein Alatas (1975), it is stated that: the corruption factor consists of internal factors (from within) and external factors (from outside). Internal factors such as greed for property, or colliding with an urgent need that triggers someone to commit corruption. Meanwhile, external factors such as the government system provide opportunities for corruption, weak legal oversight, and lack of accountability. Internal factors come from within oneself, namely the nature and character of a person that influences all his actions. Moral character is an evaluation of an individual's qualities that imply a variety of attributes including the existence or lack of virtues such as integrity, courage, fortitude, honesty and loyalty. Moral character denotes attitudes and behaviors that describe behavior in a pattern that consistently functions across a variety of situations. In Greek it comes from the word character which was originally intended as a sign of impressions or coins, and later developed into a point that distinguishes one individual from another. There are two approaches that can be used as an understanding of moral character, namely: normative ethics and applied ethics. Normative ethics shows as a distinction between right behavior and wrong behavior. Meanwhile, applied ethics is an action that responds to certain issues with a choice of moral considerations. Campbell and R. Bond, in 1982 conveyed that as the main factors affecting character and moral development, are heredity, childhood experiences, modeling by important older adults and adolescents, peer influence, general physical and social environment, the media of communication, what is taught in schools and other institutions, and the specific situations and roles that give rise to appropriate behavior. Character becomes an identity that marks its mental and ethical nature as a form of accumulation, starting with thoughts, values, words and actions. Mind is the most important element in character building because it is formed in it from several experiences in his life. If his thoughts form beliefs that are in accordance with ethics and social values in general, it will result in an action that brings calm and happiness. On the other hand, if his belief deviates from ethics and social values it will result in misery and suffering. In addition, the formation of a person's character / personality is influenced by several factors, namely Biological, Geographical, Cultural, Group Experience, and Ethical or Moral Values. Biological factors that are intended to shape a person's personality are physical factors and not genetic inheritance. A child's personality may differ from his biological parents depending on his socialization experience. Meanwhile, the geographical factor is the condition of the physical environment (climate, topography, natural resources) and the social environment, because a person has to adjust to his environment. Cultural factors have a major influence on a person's behavior and personality, especially the cultural elements that directly affect individuals. Culture can be a guide for a person's life in fulfilling his life's needs. Therefore, the cultural elements that develop in society will always be studied and understood so that different personalities are formed between individuals or between cultural groups from one another. The group experience factor for a person is quite important in his role in the development of his personality, there are two influential 
groups, namely the reference group (reference group). In general, a person's personality development will be influenced by the group that is his reference, especially the family because it will be the main reference in addressing and understanding any developing issues. Meanwhile, other groups that are influential in the formation of a person's personality are plural groups, mainly showing the development of culture in their social environment, so that they will become beliefs and try to defend their rights in dealing with various problems.

Meanwhile, ethical or moral values also influence the formation of a person's character. There is a lot of information received by someone from outside, for example information regarding violence in the family, information about corruption, promiscuity is pride, sex has become a habit, abortion is something that is normal, and so on. From the various information, then someone will respond and think according to their capacity and quality. The occurrence of moral deviations today is rooted in the absence of religious values which have implications for the weak personality and character of each individual or group. From this, actually this is where religion has a very urgent role, especially in terms of personality formation. The role of religion includes: The source of individual and group life guidelines, regulating the procedures for human relations with God and humans with humans, constituting demands for the principle of right or wrong, guidelines for expressing a sense of togetherness, guidelines for feelings of belief, guidelines for civilization, guidelines for recreation and entertainment, disclosure of aesthetics (beauty), and giving identity to humans as people of a religion (wordpress.com $>2014 / 04 / 13>$ forming ....). In the process of forming a person's personality, it is necessary to instill religious values so that someone is able to recognize the rules of behavior in accordance with the teachings of the religion that is followed, so that someone in taking an action will always consider good and bad. In addition, social values shared by members of the community also shape one's personality. Value is a set of habits or rules that are recognized as true by all members of society in order to create an orderly community life, and also bind individuals as part of a round and whole community group. A person's character which is formed from various factors will later become the basis for considering each of his actions. The value of something that is considered important in life encourages people to take actions that are oriented towards their achievement, even though the methods that are done deviate from social values.

Meanwhile, external factors that cause corruption come from the surrounding environment which can influence a person's thoughts and actions so as to commit corruption. Some of which are included in these external factors include: legal, political, economic, organizational and social factors. For example, from the legal aspect related to law enforcement, according to Soerjono Soekanto (1983: 4-5), he said that law enforcement is a means which contains values or concepts about justice, truth, social benefits and the content of law is abstract. Concrete law enforcement is the enactment of positive law in practice as it should be obeyed. Therefore, the success of law enforcement is influenced by 5 factors that influence law enforcement, namely: (a) the legal factor itself; (b) Law enforcement factors, namely the parties who form or enact laws; (c) The factor of means or facilities that support law enforcement; (d) Community factors, namely, the environment in which the law applies and is applied; (e) Cultural factors, namely, as a result of taste creations based on human initiative in social life. Besides that, political factors also often become the reason for someone to commit a criminal act of corruption, because the political costs that must be incurred when wanting to occupy a public office are very high. This condition encourages someone to abuse and / or abuse their power for personal gain.

Several factors triggered the corruption, one of which was the ineffective application of accountability in the management of public institutions. Law Number 28 of 1999 concerning state administrators who are clean and free from corruption, collusion and nepotism in which the principle of openness and accountability is one of the main principles in the instrument of state administration. Accountability is one of the principles in the framework of realizing Good Governance or good governance. With the spirit of realizing Good Governance, by itself it can become an instrument in the prevention and eradication of corruption at the same time. One of the entry points for the potential for corruption to start with the poor performance of public services, therefore, in line with reforming governance practices, improvements in the public service sector should also be initiated. According to Dwiyanto et.al (2006), public service is chosen as the main driving force because efforts to realize the values that have characterized good governance practices in public services can be done more clearly and easily. Values such as efficiency, transparency, accountability and participation can be interpreted relatively easily in the delivery of public services. Public service performance requires concrete action in realizing accountability, transparency and public participation. Accountability and transparency are forms of commitment that must be started from the person of the public official, because with this intention it will keep attitudes and behaviors that deviate from the applicable provisions. Likewise, improvements in the performance of public services also require the participation of the community to participate in monitoring in order to minimize the occurrence of deviant actions when public officials provide services to the community. Furthermore, Sedarmayanti (2004) explains that: the implementation of good governance is a prerequisite for any government to realize the aspirations of society and achieve the goals and ideals of the nation and state. In this context, it is necessary to develop and implement a system of accountability that is precise, clear and legitimate, so that the administration of government can take place in an efficient and responsible manner. Good governance is at the same time a goal, because the realization of good 
governance means the realization of people's aspirations in the process of governance.

Thus, good governance requires accountability in every regulation and action carried out by government officials. Therefore, every government institution must always be willing to take responsibility for all activities that become its duties and functions. Accountability is not only needed by the government but also by the community. Accountability for the community must also be accompanied by the existence of adequate facilities and infrastructure so that they can easily access all information that develops regarding the policies and work programs being carried out. This access and channel needs to be established by the government so that all community groups can access information because it is a form of equal rights and opportunities in utilizing these channels. Based on Law No. 28 of 1999 states the general principles of state administration include: the principle of legal certainty, the principle of orderly state administration, the principle of public interest, the principle of openness, the principle of proportionality, the principle of professionalism and the principle of accountability. The principle of accountability is the principle that determines that each and every end result of state administration activities must be accountable to the public or the people as the holder of the highest state sovereignty in accordance with the provisions of the prevailing laws and regulations. In this regard, it is necessary to have a system of accountability that is precise, clear, legimate, which can guarantee that the administration of government is effective, effective, clean and responsible, and is free from corruption, collusion and nepotism. Accountability means that a government institution has set and has a clear vision, mission, goals and objectives for the work program that has been, is being, or will be implemented. With accountability, it can also be measured how they organize and maintain (hold) their responsibility for achieving results.

Based on the Guidelines for the Compilation of Government Agency Performance Accountability Reporting (LAN-BPKP, 2000), accountability is an obligation and obligation for every government institution to convey accountability to the public, and is obliged to explain and explain to the public when there are questions from the public. Accountability is the basis of all government processes and effectiveness in government administration. Accountability is believed to be able to minimize the occurrence of criminal acts of corruption, because the performance of government institutions is directed at efforts to achieve broader national goals with the highest levels of efficiency, effectiveness, honesty and wisdom. According to Ellwood in Manggaukang (2006), process accountability is related to whether the procedures used in carrying out tasks are good enough in terms of the adequacy of accounting information systems, management information systems, and administrative procedures. Process accountability is manifested through the provision of public services that are fast, responsive, and inexpensive. Meanwhile, according to David Hulme and Mark Turner argued that: accountability is a complex concept and has several instruments to measure it, namely the presence of indicators such as: (1) legitimacy for policy makers; (2) the existence of adequate moral qualities; (3) sensitivity; (4) openness; (5) optimal use of resources; and (6) efforts to increase efficiency and effectiveness (Manggaukang, 2006). The prerequisite for the realization of accountability requires legitimacy from policy makers or actors, because a high level of public trust will encourage people to believe in and follow the results of their policies. On the other hand, if policy makers lack legitimacy in the eyes of the public, it can raise potential suspicion and in the end, they will not receive enough support from the public.

Thus, the problem is that the level of public accountability is still relatively low, which encourages corruption, collusion and nepotism in the bureaucratic environment. In addition, the level of compliance with laws or regulations has not been enforced in carrying out bureaucratic duties, so that its enforcement is very weak, the use of power that exceeds the limits of reasonableness, weak mental control of leaders, officials and administrators of the government bureaucracy. From the above thinking, a concept is produced that the accountability of the performance of the public bureaucracy has an effect on corruption, collusion and nepotism. For this reason, the following hypothesis constructs a relationship between variables, namely:

1. Ho $=$ There is an influence between the accountability of the performance of the public bureaucracy on corruption, collusion and nepotism (KKN),

2. $\mathrm{Ha}=$ There is no influence between the accountability of the performance of the public bureaucracy on corruption, collusion and nepotism (KKN).

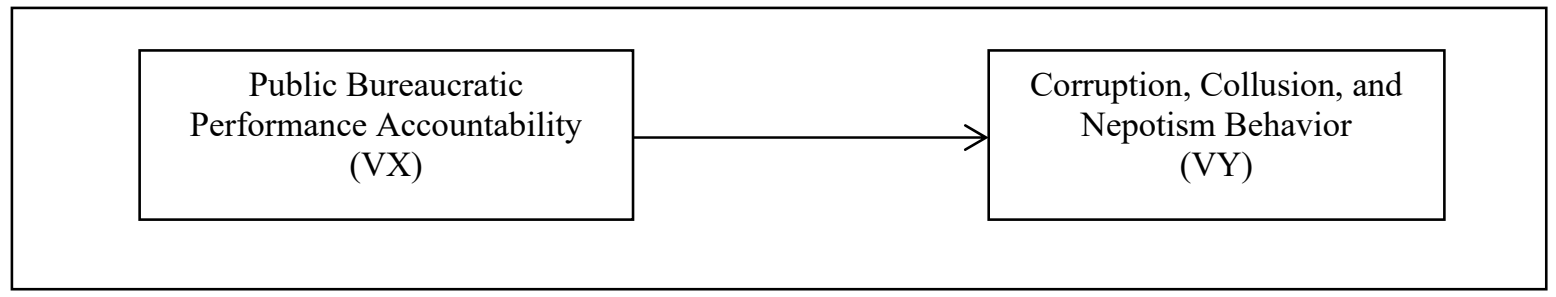

RESEARCH METHODS.

This study uses a quantitative approach to determine the respondent's assessment of the accountability of the 
performance of the public bureaucracy and the behavior of corruption, collusion and nepotism (KKN). Data were collected through distributing questionnaires to 150 respondents who were randomly selected in 6 sub-districts, Ponorogo Regency. Each sub-district was assigned 25 respondents by random sampling, consisting of: 8 employees and 17 service users. The respondent's assessment is measured using a Likert scale with a gradation from very positive to very negative, in the form of words including: a) Strongly agree with a score of 5, b) agree with a score of 4, c) Doubtful with a score of 3,d) No agree with score 2, and e) Strongly disagree with score 1. While the data analysis method uses a regression analysis model with processing through SPSS.

\section{RESULTS AND DISCUSSION.}

\section{Correlation Test}

To test the hypothesis, a correlation test was carried out between the bureaucratic performance accountability variable (VX) as the independent variable on the corruption, collusion and nepotism behavior (VY) as the dependent variable. The results of the correlation test are as follows:

Table. 1

Public Bureaucratic Performance Accountability Relationship against corruption, collusion, and nepotism behavior

Correlations

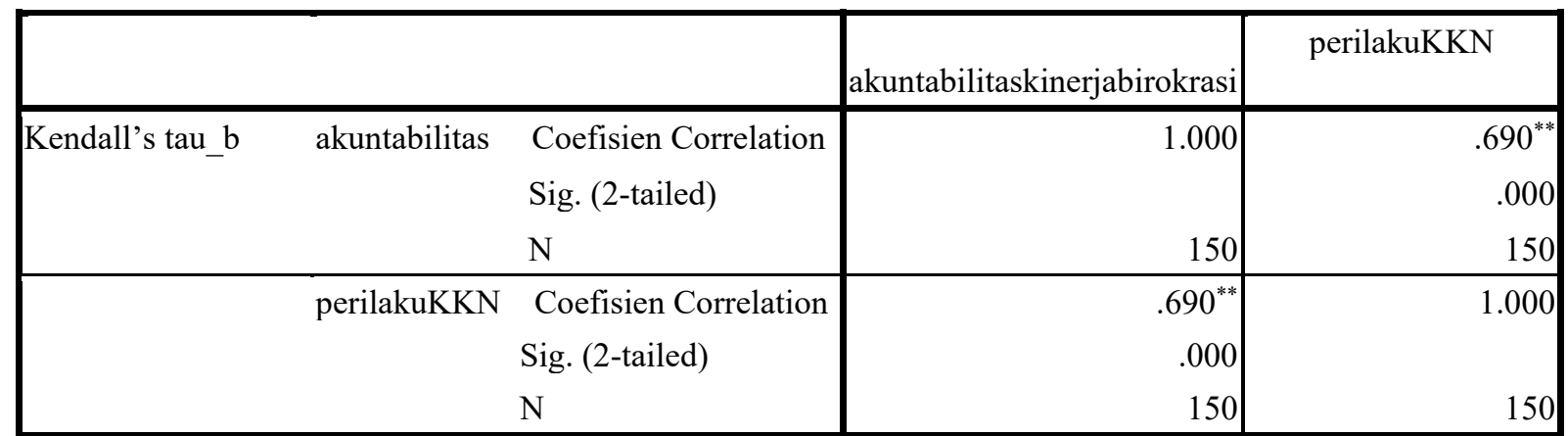

**. Correlation is significant at the 0.01 level (2-tailed).

From the table above, the correlation value between the Bureaucratic Performance Accountability variable and the corruption, collusion, and nepotism behavior variable (Corruption, Collusion, and Nepotism) is 0.690 with a $\mathrm{p}$-value $=0.000$. When compared with the value $\alpha=0.05$, it is known that the $\mathrm{p}$-value $=(0.000)<\alpha(0.05)$. Thus, the hypothesis $\mathrm{Ha}$ is accepted, that is, there is a correlation between the Accountability of Bureaucratic Performance with corruption, collusion, and nepotism behavior.

Regression Test

The results of the regression calculation between the accountability variables of the performance of the public bureaucracy on KKN behavior (corruption, collusion, and nepotism) are:

Table. 2

Effect of Public Bureaucratic Performance Accountability against corruption, collusion, and nepotism behavior

Coefficients $^{\mathrm{a}}$

\begin{tabular}{|c|c|c|c|c|c|}
\hline \multirow[b]{2}{*}{ Model } & \multicolumn{2}{|c|}{ Unstandardized Coefficients } & $\begin{array}{c}\text { Standardized } \\
\text { Coefficients }\end{array}$ & \multirow[b]{2}{*}{$\mathrm{t}$} & \multirow[b]{2}{*}{ Sig. } \\
\hline & $\mathrm{B}$ & Std. Error & Beta & & \\
\hline (Constant) & 6.501 & 3.154 & & 2.061 & .041 \\
\hline akuntabilitaskinerjabirokrasi & .963 & .058 & .806 & 16.563 & .000 \\
\hline
\end{tabular}

a. Dependent Variable: perilakuKKN

From the regression equation $(\mathrm{Y}=\mathrm{a}+\mathrm{bX}$ ), it can be identified: (1) Constant value 6,501; shows that corruption, collusion, and nepotism behavior will be constant if the accountability variable for bureaucratic performance is zero (non-existent), assuming other factors remain or do not change in value. (2) The corruption, collusion, and nepotism behavior variable which has a value of 0.963 (positive) indicates the effect of the accountability of the bureaucratic performance on the corruption, collusion, and nepotism behavior. If the accountability of the bureaucratic performance increases by 1 unit, the corruption, collusion, and nepotism behavior will also decrease by 0.963 . Thus the accountability of bureaucratic performance has a positive effect on corruption, collusion, and nepotism behavior.

Determination Test.

The coefficient of determination (R2) is used to measure how far the model's ability to explain variations in the 
dependent variable (Ghozali, 2006). The results of the determination coefficient test are:

Table 3

Results of the Determination Test between the accountability variables of the performance of the public bureaucracy and corruption, collusion and nepotism

Model Summary

\begin{tabular}{|l|r|r|r|r|}
\hline Model & \multicolumn{1}{|c|}{$\mathrm{R}$} & \multicolumn{1}{|c|}{ R Square } & Adjusted R Square & Std. Error of the Estimate \\
\hline 1 & $.806^{\mathrm{a}}$ & .650 & .647 & 5.649 \\
\hline
\end{tabular}

a. Predictors: (Constant), akuntabilitas kinerja birokrasi

b. Dependent Variable: perilaku KKN

The amount of Multipe Coefficient of Determination ( $\mathrm{R}$ Square) is 0.650 or $65.0 \%$, which means that Corruption, Collusion, and Nepotism behavior can be explained by the accountability variable for bureaucratic performance, while the remaining $35.0 \%$ is explained by other variables not explained in the study. Corruption, Collusion, and Nepotism behavior is highly dependent on the accountability of the bureaucratic performance, because Corruption, Collusion, and Nepotism behavior is an act that deviates from the applicable regulations for the sake of personal or group interests Corruption is the embezzlement of state resources by government officials, so with accountability for policies in government administration, to prevent corruption. Accountability is explicitly a form of responsibility of government officials for the implementation of their duties and functions, while implicitly accountability is the responsibility of government officials for their policies and actions implemented. if government officials have a vision and mission as a public servant, it will keep corrupt behavior away and prioritize public interests. Prevention of corruption in public bureaucracy is not only carried out by stipulating laws and regulations by imposing severe penalties, but far more important is the commitment and responsibility of all government officials to avoid corruption.

\section{CONCLUSION}

The main factors that trigger corruption are moral, legal, economic and political factors. The low integrity attitude of public officials encourages acts of abuse of power and authority in carrying out their duties and functions. Besides that, the weakness in law enforcement, as well as the political cost of holding a public office, is very large, thus encouraging someone to misuse public funds for their personal interests. This can be minimized the occurrence of corruption through accountability for the performance of the public bureaucracy, because the principle of accountability will encourage and grow an attitude of integrity in a person, which can be the main antidote to acts of irregularities. Therefore, it takes ethical and moral values to be instilled as early as possible in government employees, so that they carry out their duties and functions according to the vision and mission of each institution.

\section{CONFLICT OF INTEREST}

There is no conflict of interest.

\section{ACKNOWLEDGMENTS}

This article is sponsored by the Kemenristik-Dikti Indonesian Research Grants Program.

\section{REFERENCES}

Ardito Ramadhan, 2020, Kompas.com dengan judul "Catatan ICW, Tren Penindakan Korupsi Turun Jadi 271 Kasus", https://nasional.kompas.com/read/2020/02/18/ 16532131/ catatan-icw-tren-penindakan-korupsiturun-jadi-271-kasus.

BPKP, 1999, Strategi Pemberantasan Korupsi Nasional, Pusat Pendidikan dan Pengawasan BPKP, Jakarta.

Dwiyanto, et.al, 2006, Mewujudkan Good Governance Melalui Pelayanan Publik. Yogyakarta: Gajah Mada University Press

Ghozali, Imam, 2006, Aplikasi Analisis Multivariate Dengan Program SPSS, Badan Penerbit Universitas Diponegoro, Semarang.

Raba,Manggaukang, 2006, Akuntabilitas Konsep dan Implementasi, Penerbit UMM Press, Malang.

Syed Hussein Alatas, 1975, Sosiologi Korupsi, Penerbit: LP3ES, Jakarta.

Soerjono Soekanto, 1983, Faktor-faktor yang mempengaruhi Penegakan Hukum, Penerbit PT Raja Grafindo Persada, Jakarta.

Undang-Undang Nomor. 31 tahun 1999 tentang Pemberantasan Tindak Pidana Korupsi

Undang-undang Nomor 28 tahun 1999 tentang penyelenggara negara yang bersih dan bebas dari korupsi, kolusi dan nepotisme

Kompos.com, 2017,"Labirin Praktik Korupsi", $\quad$ https://nasional.kompas.com/read/2017 $\quad$ /01/04 /23230031/labirin.praktik.korupsi?page $=$ all. 
14 BAB II KORUPSI DAN DAMPAKNYA A. Pengertian Korupsi ..., eprints.walisongo.ac.id/ 3925/3/104211009_Bab2.pdf

KARAKTERISTIK INDIVIDU | My World, 2014, datakata.wordpress.com > 2014/04/13 > pembentuk ... 